University of Nebraska - Lincoln

DigitalCommons@University of Nebraska - Lincoln

2000

\title{
Mapping of Seven Bovine Cytokine Genes Involved in T- lymphocyte Growth, Differentiation and Immune Response
}

\author{
T. S. Sonstegard \\ USDA-ARS
}

W. M. Garrett

USDA-ARS, wesley.garrett@ars.usda.gov

G. L. Bennett

USDA-ARS, gary.bennett@ars.usda.gov

S. M. Kappes

USDA-ARS

D. S. Zarlenga

Immunology and Disease Resistance Laboratory

See next page for additional authors

Follow this and additional works at: https://digitalcommons.unl.edu/hruskareports

Sonstegard, T. S.; Garrett, W. M.; Bennett, G. L.; Kappes, S. M.; Zarlenga, D. S.; and Gasbarre, L. C., "Mapping of Seven Bovine Cytokine Genes Involved in T-lymphocyte Growth, Differentiation and Immune Response" (2000). Roman L. Hruska U.S. Meat Animal Research Center. 253.

https://digitalcommons.unl.edu/hruskareports/253

This Article is brought to you for free and open access by the U.S. Department of Agriculture: Agricultural Research Service, Lincoln, Nebraska at DigitalCommons@University of Nebraska - Lincoln. It has been accepted for inclusion in Roman L. Hruska U.S. Meat Animal Research Center by an authorized administrator of DigitalCommons@University of Nebraska - Lincoln. 


\section{Authors}

T. S. Sonstegard, W. M. Garrett, G. L. Bennett, S. M. Kappes, D. S. Zarlenga, and L. C. Gasbarre 


\section{Mapping of seven bovine cytokine genes involved in T-lymphocyte growth, differentiation and immune response T S Sonstegard ${ }^{1}$, W M Garrett ${ }^{1}$, G L Bennett ${ }^{3}$, S M Kappes ${ }^{3}$, D S Zarlenga ${ }^{2}$, L C Gasbarre ${ }^{2}$ \\ ${ }^{1}$ ARS-USDA Gene Evaluation and Mapping Laboratory, Beltsville Agricultural Research Center, Beltsville, MD 20705, USA \\ 2 Immunology and Disease Resistance Laboratory, Beltsville Agricultural Research Center, Beltsville, MD 20705, USA; \\ ${ }^{3}$ ARS-USDA Roman L. Hruska Meat Animal Research Center, Clay Center, NE 68933, USA \\ Accepted 16 July 2000}

Source/description: Radiolabelled cDNA fragments of IL10, IL12A, IL12B, IL15, IL18, TNF, and TGFB1 were generated ${ }^{1,2}$ and used as hybridization probes to isolate unique clones from the Roswell Park Cancer Institute (RPCI)-42 bovine bacterial artificial chromosome (BAC) library (URL http://www.chori.org/bacpac/42framebovine.htm). Correspondence between clones and cytokine gene probes was confirmed by BLAST analysis of BAC sequence data ${ }^{3}$ against published sequence in GenBank ${ }^{4}$. Positive BAC clones were used as a DNA source to generate probes for fluorescent in situ hybridization (FISH) and to develop microsatellite markers (Table 1). Microsatellite (ms) loci were identified and isolated by screening plasmid libraries ${ }^{5}$ created by subcloning Sau3AI digested BAC DNA $^{6}$. Microsatellites were sequenced on an ABI-377 (Perkin Elmer Corp., Foster City, CA, USA), and sequence data was queried against GenBank with BLAST to confirm singularity.

PCR conditions: Primer pairs for ms loci were designed with Primer verion 3 (Whitehead Institute for Biomedical Research, http:// www.genome.wi.mit.edu/cgi-bin/primer/primer3_www.cgi). PCR amplifications were performed on a MJ Research PTC-200 thermocycler (MJ Research Inc., Watertown, MA, USA) as described previously. ${ }^{7}$ Optimal annealing temperatures were determined for each marker by testing a range of annealing temperatures $\left(48-62^{\circ} \mathrm{C}\right)$.

Polymorphism and allele size: Amplification reactions were diluted in $\mathrm{ddH}_{2} \mathrm{O}(1: 5-1: 25)$. A sample $(1 \mu \mathrm{l})$ of diluted product was mixed with $9 \cdot 7 \mu \mathrm{l}$ of Hi-Di formamide and $0 \cdot 3 \mu \mathrm{l}$ of $400 \mathrm{HD}$ size standard (both from Perkin Elmer Corp.), and this mixture was analysed on an ABI-3700 automated DNA sequencer with GeneScan software (Perkin Elmer Corp.). Allele sizes and frequencies in the USDA Meat Animal Research Center (MARC) reference population (Table 1) were determined with Genotyper software (Perkin Elmer Corp.).

FISH analyses: Biotinylated BAC probes were synthesized with a BioNick Labeling System (GibcoBRL, Gaithersburg, MD, USA) and purified through a G-50 fine Sephadex column (Eppendorf, Westbury, NY, USA). Approximately $200 \mathrm{ng}$ of probe was co-precipitated in ethanol with $5 \mu \mathrm{g}$ sonicated salmon sperm DNA and $10 \mu \mathrm{g}$ bovine $\mathrm{C}_{\mathrm{ot}} 1$ DNA (Applied Genetics Lab., Melbourne, FL, USA). This mixture was hybridized to R-banded metaphase preparations ${ }^{8}$ to determine physical map assignments (Fig. 1). FITC and PI signals were detected with the 488 and 568-nm line, respectively, of an argon-krypton laser with a Zeiss LSM 410 confocal microscope. No chimerism was detected for the prepared probes based on detection of only one signal for each probe hybridized.
Chromosomal locations: Linkage analysis of genotypic data was performed $^{9}$ to existing linkage groups in the MARC database ${ }^{10}$ using Cri-Map version $2.4^{11}$. The most current positions on the linkage map can be accessed at http://www.marc.usda.gov/cattle. For all loci, chromosome assignments by two-point linkage analysis (Table 1) corresponded to the physical assignments by FISH (Fig. 1). In addition, the map placement of $B B 717$ and BB705 agreed with genetic mapping of $I L 10^{12}$ and $T N F^{13}$, respectively. Comparative map alignment of the seven cytokine genes was in agreement with previously defined regions of conserved synteny between the bovine and human maps (http://bos.cvm.tamu.edu/htmls/BHM.html). Alignment of the bovine and mouse physical maps also agreed with the exception of the IL15 assignment, which identified a conserved genomic segment shared by BTA17 and mouse chromosome 8 . The cytokine gene associated ms markers will be potentially useful for identifying the genomic locations of disease related traits.
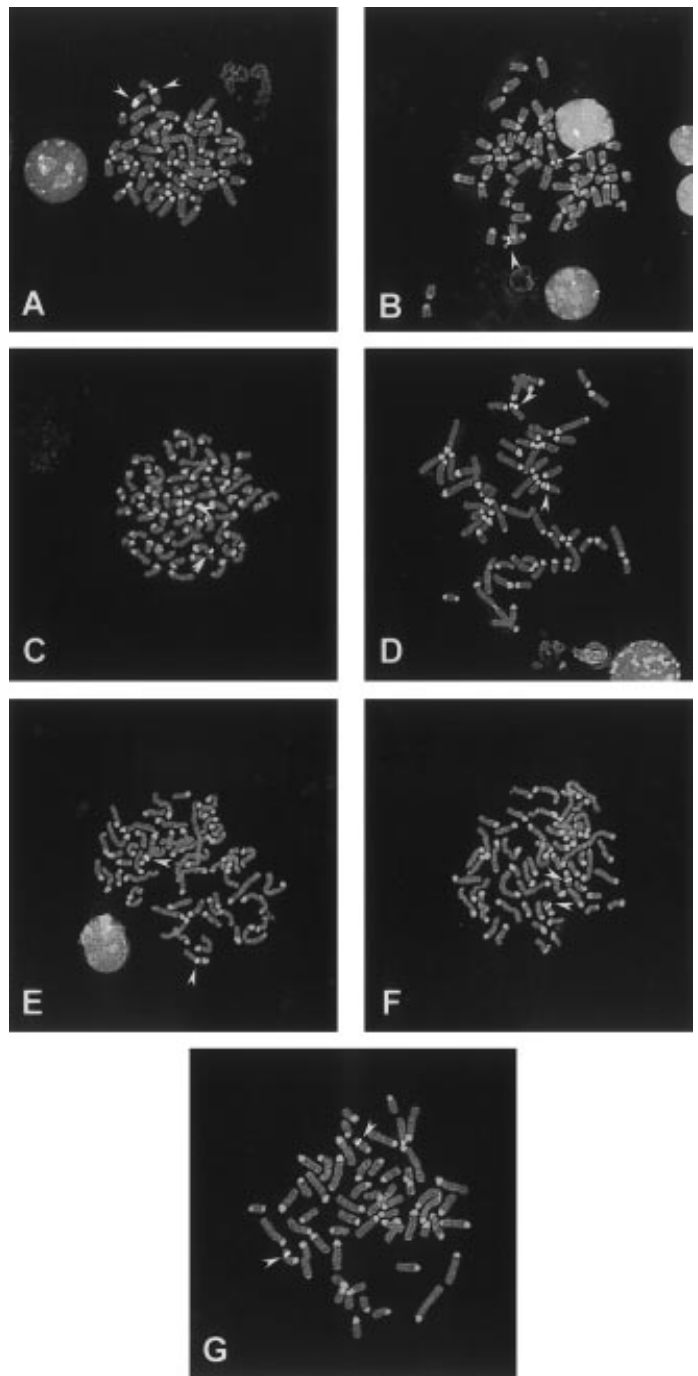

Fig. 1. FISH analyses of seven bovine cytokine loci with FITC hybridization signals derived from BAC DNA probes shown ${ }^{14}$. White arrowheads point to the location of the detected fluorescence probe signal in each panel. The panel displays the following: (A) BAC $45 \mathrm{~K} 19^{*}$ (IL10) probe to BTA16q1.2, (B) BAC 134 L14 (IL12A) probe to BTA1q3.4-q3.6, (C) BAC 135 O11 (IL12B) probe to BTA7q2.3-q2.4, (D) BAC 97 E15 (IL15) probe to BTA17q1.3-q1.4, (E) BAC 206 E9 (IL18) probe to BTA15q1.3-q1.4, (F) BAC 42J 20 (TNF) probe to BTA23q2.1-q2.2, (G) BAC 96 M1 (TGFB1) probe to BTA18q2.4-q2.5. *Indicates plate and well address of BAC clone in RPCI-42 library. 


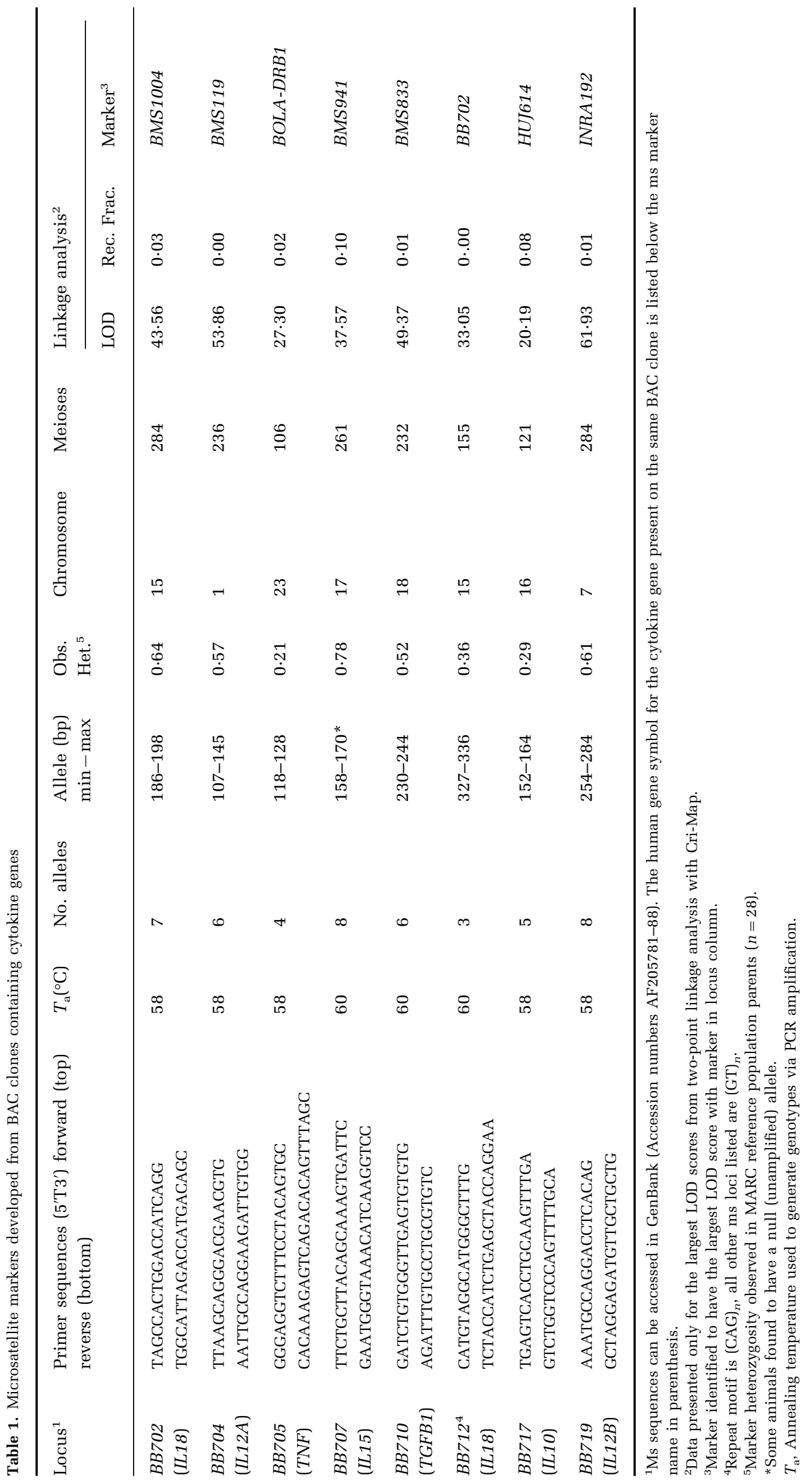


Acknowledgements: We wish to thank Tina DeLuca for superior effort and technical assistance; and Shirley Weese for secretarial assistance. We are grateful to Dr. D.S. Gallagher for technical advice related to the FISH protocol. Mention of trade names or commercial products in this article is solely for the purpose of providing specific information and does not imply recommendation or endorsement by the US Department of Agriculture.

\section{References}

1 Almeria S. et al. (1998) Vet Parasitol 15, 53-64.

2 Shoda et al. (1999) J Interferon Cytokine Res 19, 1169-77.

3 Kelley J.M. et al. (1999) Nucleic Acids Res. 27, 1539-46.

4 Benson D. et al. (1993) Nucleic Acids Res 21, 2963-5.

5 Stone R.T. et al. (1995) Mamm Genome 6, 714-24.

6 Sonstegard T.S. et al. (1998) Animal Genet 29, 341-7.

7 Sonstegard T.S. \& Kappes S.M. (1999) Animal Genet 30, 473

8 DiBerardino D. \& Iannuzzi L. (1982) J Heredity 73, 434-8.

9 Kappes S.M. et al. (1997) Genome Res 7, 235-49.

10 Keele J.W. et al. (1994) J Comp Biol 1, 65-76.

11 Green P. et al. (1990) Washington University School of Medicine, St Louis, MO, USA.

12 Beever J.E. et al. (1997) Mamm Genome 8, 533-6.

13 Grosse W.M. et al. (1999) Mamm Genome 10, 1062-9.

14 Lichter P. et al. (1990) Science 247, 64-9.

Correspondence: T S Sonstegard (e-mail: tads@lpsi.barc.usda.gov) 